\title{
口内法による咬筋肥大症手術について
}

\author{
高橋庄二郎・黄 国 和・斉藤 カ・杉崎 正志
}

岡野昌治・柴田考典・杉山紀子*

\section{Intraoral surgical correction of masseteric muscle hypertrophy}

\author{
Shojiro Takahashi - Kunikazu Ko - Chikara SaIto - Masashi Sugrsaki \\ Masaharu Okano - Takanori Shibata - Noriko Sugryama*
}

は じめに

咬筋肥大症は審美的障害のほかに，ときとして開口障 害, 開口時の過緊張, 咬筋部の不快感ないし圧痛, 靧関 節部の疼痛, 咀畄障害, 片頭痛などのごとき機能障害を 伴う。このような機能障害に対しては精神安定剤や抗疘 戀剂の投与, bruxism の解除, 片側性咬合の是正, 咬合 調整, 補綴物による咬合再建のごとき保存的療法が行わ れるが，審美的障害に対しては外科的治療が行われない 限り,これが全く改善されることがないといわれてい $ろ^{1)}$

咬筇肥大症の外科的修正手術には口外法 2 6) と口内 法1,7 10) とがあるが，本手術は審美的障害の改善が主目 的であることから, 顔面に瘢痕を残す口外法よりも口 内法が望ましいことは当然である。最近 Beckers ${ }^{1)}$ は Obwegeser によって開発された口内法による咬筋肥大 症手術の詳細を発表したが, 本法は従来の方法に比べて きわめて安全確実な方法であると考兄られる，わたくし たちは咬筋肥大症の 2 例に本手術法を行い, 良好な結果 を得たので報告する。

\section{Obwegeser-Beckers 法の概要}

下䫇枝前縁上方部から下顎第 1 大曰歯付近の兓煩移行 部に至る粘膜切開を施し，下顎枝および下罘体外側の骨 膜上剝離と咬筋付着部の切離を行 . 次いで, 咬筋下方 部の深層拈よび中間層を水平的に切断し, 同部から上方

東京菌科大学口腔外科学教室第 2 講座（主任：高 橋庄二郎教授)

* 東京桨科大学口腔外科学教室第 1 俩座（主任：大 森清弘教授)

The Second Department of Oral Surgery, Tokyo Dental College (Chief: Prof. Shojiro Takahashi)

* The First Department of Oral Surgery, Tokyo Dental College (Chief: Prof. Kiyohiro Omori) 受付日：昭和55年 6 月 9 日
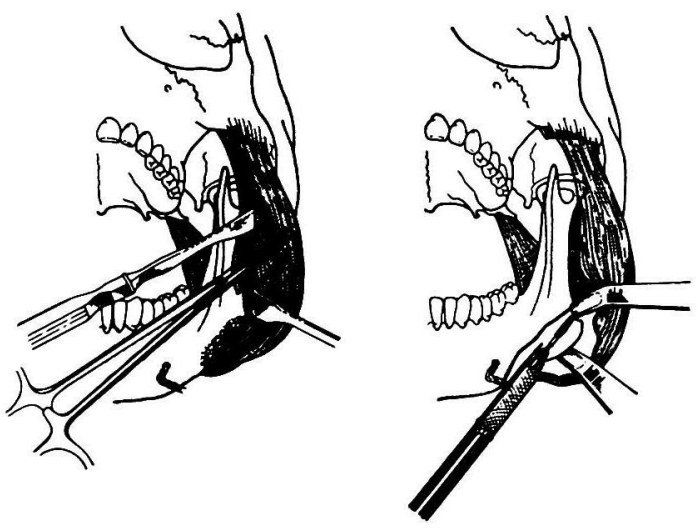

図 1 Obwegeser-Beckers 法

に向かって頓骨弓付着部付近まで，剪刀を用いて咬筋を 中央部付近で 2 層に 分割し，Allis 鈤子で把持した内側 の咬筇を切除する。続いて，下顎角部の骨膜剥離を行 い，外下方に笑出した下罘角を burを用いて切除した のち, 剥離された咬筋付着部之内側翼突筋付着部を確実 に縫合し，さらに粘膜創の完全閉鎖をはかり手術を終え る（図 1)。一般に本手術では手術野の 明視が困難であ る.わたくしたちは fiber optics 付きの鉤 ${ }^{11} を$ 用いて明 膫な視野を得ている。また術後の著明な顔面浮腫の出現 と手術部に蛙ける血連形成を予防するため, 術後 $2 \sim 3$ 日の間 Port-Vac®による持続四引を行っている.

症例

症例 1

患 者: 24歳 男性

初 診: 昭和52年11月

主 訴：両側下顎角部の膨隆および下買前突による審 美的障害.

家族歴および一般既往歴：母親および同胞に下顎前突 症を認めた以外に特記すべき事項はない，

現病歴 : 小学生時より下顎角部の膨隆と下顎前突感を 


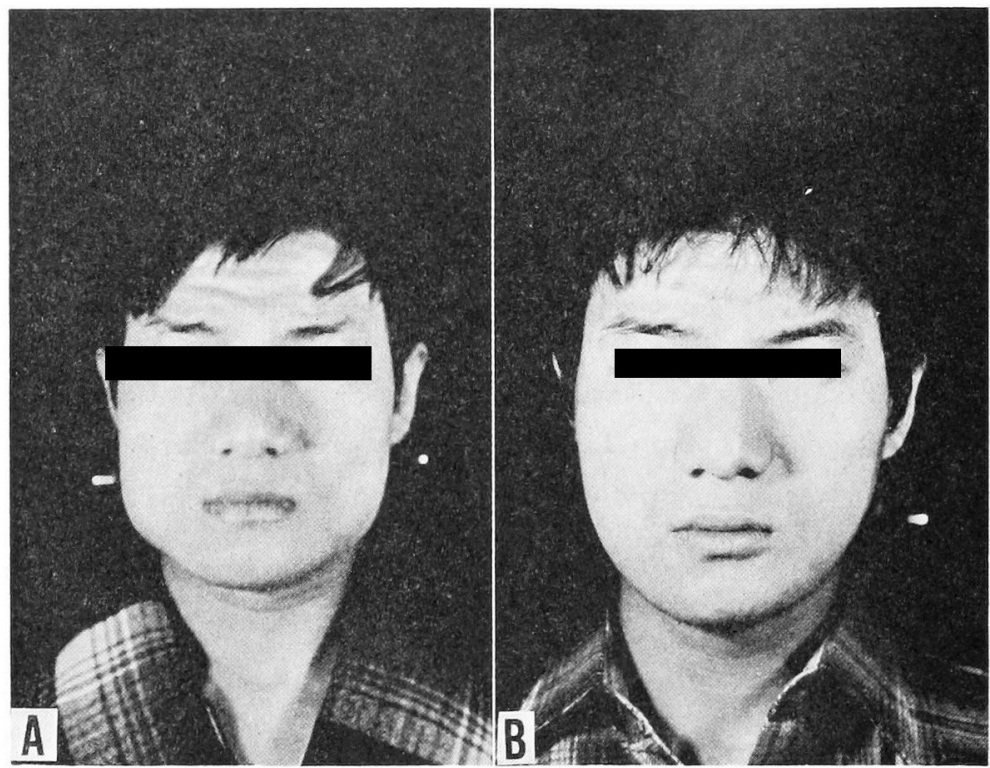

写真 1 症例 1 の顔貌所見

$\mathrm{A}$ ：術前正貌所見，B：術後正貌所見

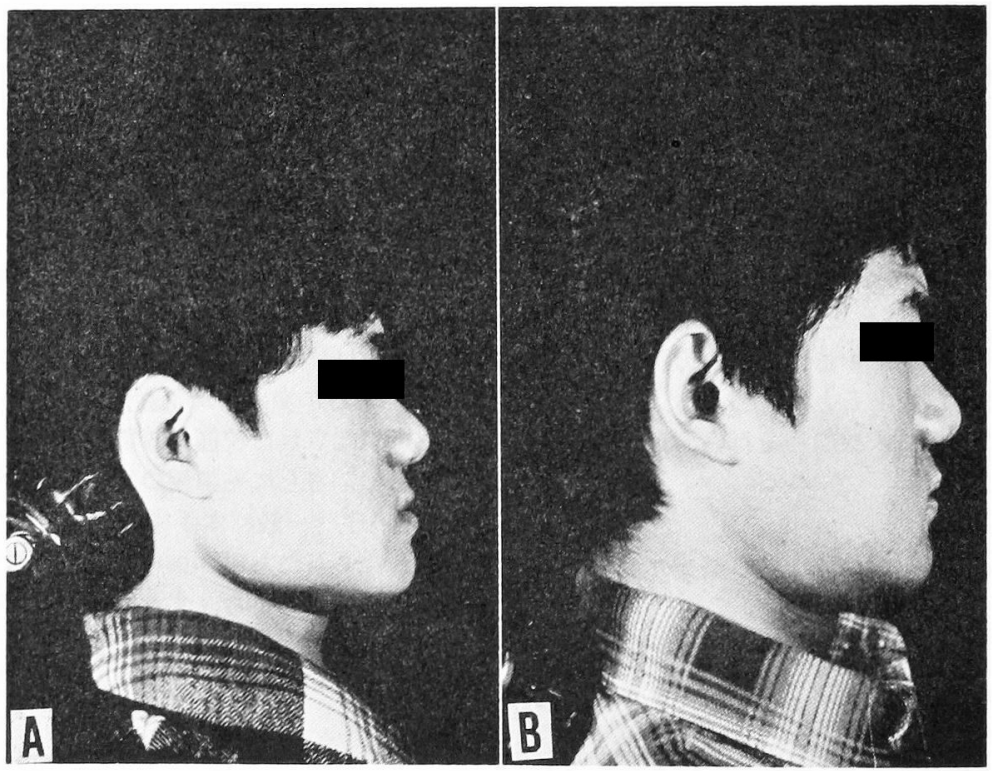

写直 2 症例 1 の顔貌所見

A：临前側貌所見, B：術後側貌所見

自覚するも放膡, 高校卒業時頃より顔貌に少等感を感 で，手術を希望して来院した。

現 症：全身的には体格中等度，栄着状熊良好で，血 液，尿愉查等で異常はみられなかった，顔貌所見として は，顔色良好で，外形はやや角張っており，両側耳下腺 咬箊部および下顎角部に膨隆を翟めた。顔面は左右非対
称を示し，右側は左側よりも軽度に膨隆していた（写真 1-A)，両側耳下腺咬筋部は弹性軟で 皮膚に異常はみら れなかったが，咬みしめ時にやや固い咬筇の膨隆を触知 した。側貌においては下唇およびオトガイ部の軽度前突 を認めた（写真 2-A）。 またオトカイ下部方向からの観

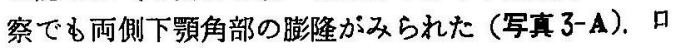




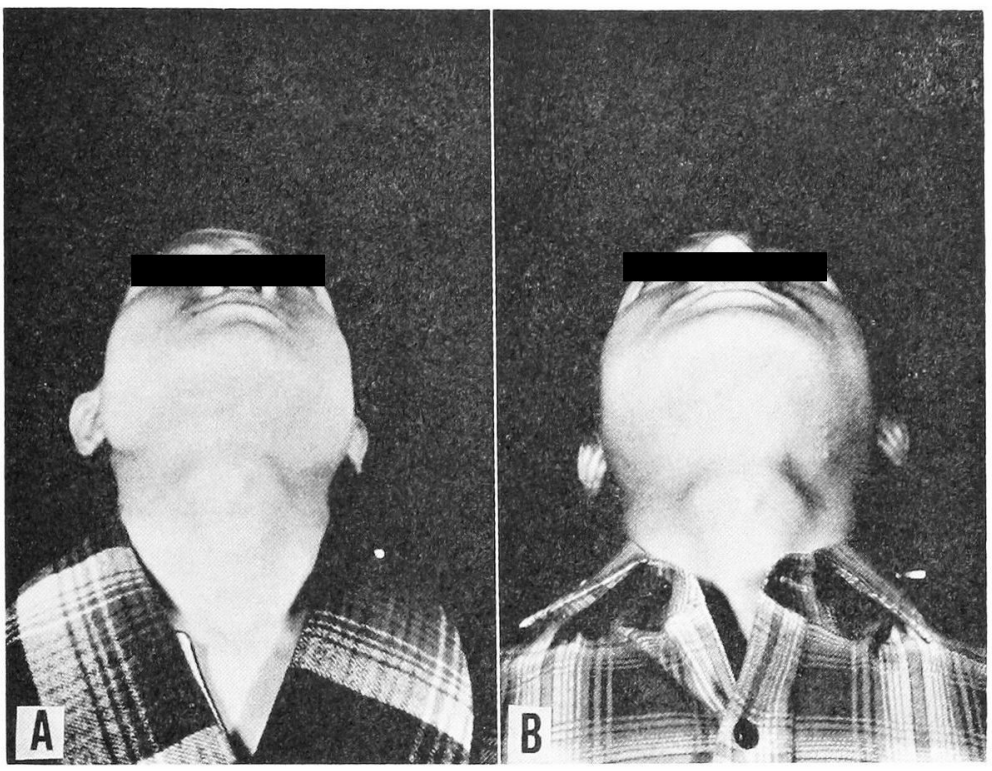

写真 3 症例 1 の顔貌所見

$\mathrm{A}$ : 術前オトガイ下方部からの所見， $\mathrm{B}$ ：術後オトガイ下方部からの所見

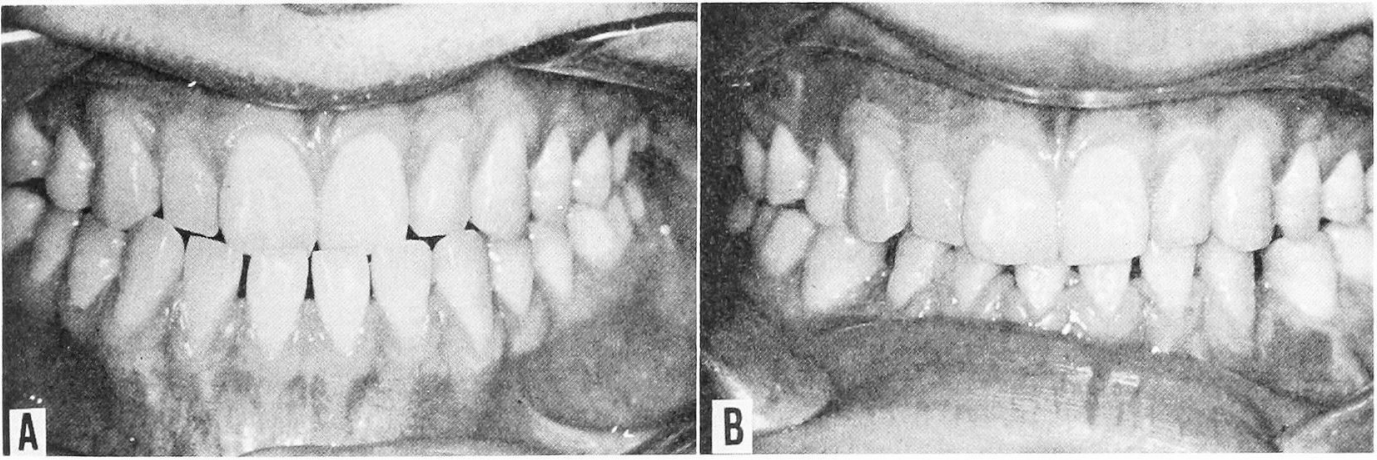

写真 4 症例 1 の口腔内所見

$\mathrm{A}$ : 㧓前口腔内所見， B：術後口腔内所見

腔内症状としては，咬合は Angle の川級を是し，前方 歯群の反対咬合が認められたが，開閉口時の顎偏位や bruxism 等の習慣はみられなかった (写真 4-A).

$\mathbf{X}$ 線所見：正貌の軟組織頭部 $\mathbf{X}$ 線規格写真で両侧下顎 角部の異常突出がみられた（写真 5-A）。また函科用グ ラディコン万能分析装監によるセファロ分析の結果, 当教室に拉ける分類で Type 1 Group B であった（図 2).

処置および経過 : 以上の所見より下顎前突症および両 側咬筋肥大症之診断 し, 昭和53年 1 月 気管内麻酔下 K anterior alveolar osteotomy および前述の Obwegeser-Bekers 法による咬筋肥大症手術を施行した。咬筋 切除量は両側と多約 $4 \mathrm{~g}$ で，下顎角部の骨切除量は左側
より右側において，やや多くなるように努めた（写真 6). また術後の浮腫出現と血腫予防のため Port-Vac@ による持続吸引と圧迫包帯を施行した。なお開口訓練は 術後21日目より始めた。術後 5 か月経過時の顔貌所見で は，下顎角部の膨隆はかなり軽減し，外形は丸顔にな り，左右対称性となるとともに profile るかなり改善さ れた（写直 1-B，2-B）。 オトガイ下部方向からの観察 でも下顎角部の膨隆は明らかに減少していた（写真了B ). 生珓合状態も著しく改善され，術後の機能障害 む全く認められなかった.

症例 2
患 者
24歳 男性.
初 診: 昭和54年10月 


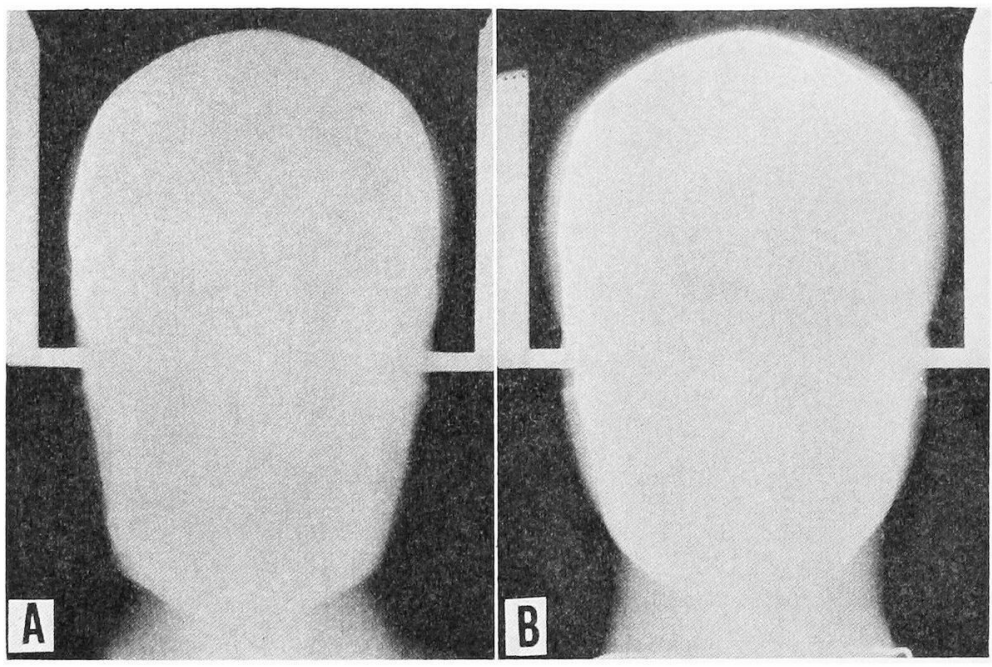

写真 5 症例 1 の正貌の歌組織頭部X線規格写真

A：政 前, B：㭪 後

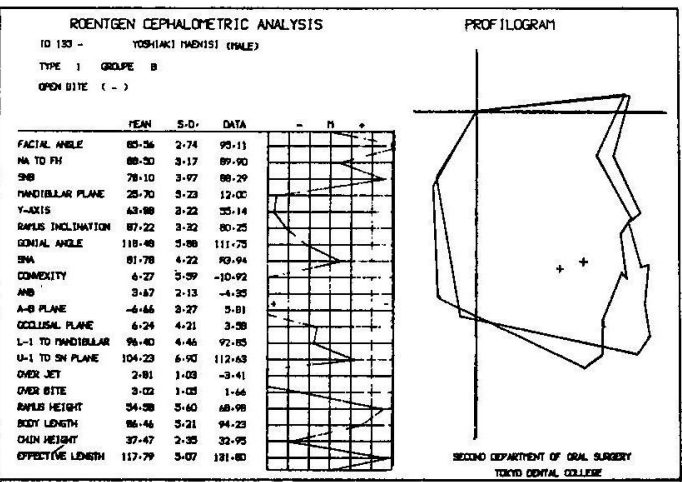

図 2 症例 1 のセファロ分析結果

主 訴：両側下顎角部突出による番美的障㽞. 家族歴およびー般既往歴：特記事項なし.

現病歴 : 昭和54年 7 月頃より両側下顎角部の突出を自 覚するととるに，同部の異和感，咬筇部不快感を認め， 精神的に不安を感じ来院した。

現 症：全身的には体格中等度，栄荃状態良好で，血 液，尿検查等で異常はみられなかった．顔貌所見として は，顔色良好で，外形はやや角張って拈り，両側耳下腺 咬筋部および下顎角部に膨隆を認めた（写真 7-A）。 た咬みしめ時には両側咬筋部に固い咬筋を触知した，口 腔内所見には変化はみられず， bruxism 等の習游は認め られなかったが，交筋部の不快感を訴えた。

$\mathbf{X}$ 線所見：正貌の頭部 $\mathbf{X}$ 線規格写真において，両側の 下影角部に骨性張開が認められた（写直 8-A）.

処置および経過：以上の所見より両側の珓筋肥大症と 診断し，昭和54年12月—気管内麻酥下に，前述の咬筋

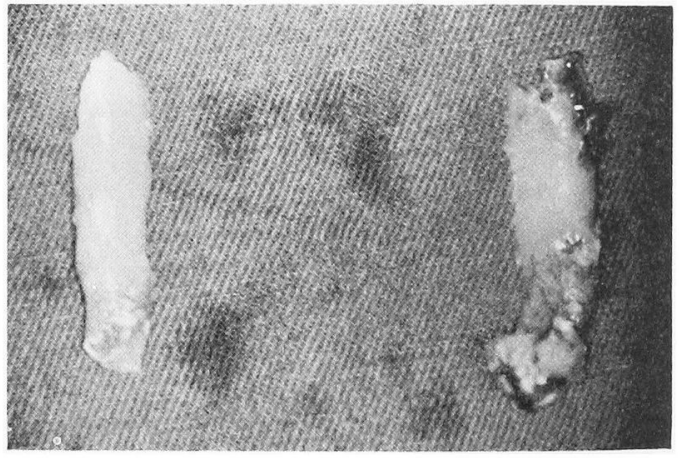

写真 6 症例 1 の下顎角部切除骨片

肥大症手術を施行した。本症例でも同様に咬筋と下靧角 部の切除を行い，咬䇗の切除量忶右側が約 $4 \mathrm{~g}$, 左側が 約 $3 \mathrm{~g}$ であった. Port-Vac® は術後 2 日目に除去した。 開口訓練は術後疼痛が忹ぼ消失した術後 5 日目より開始 し，術後12日目には術前とほぼ同様の状態にまで開口が 可能となった，術後 4 か月の顔貌所見では，下筫角部の 膨隆はほとんど消失し，外形は卵形を呈していた（写真 7-B). 正貌頭部X線規格写真において，下顠角部の骨 性張開は全く烈められなかった（写真 8-B）。また初診 時にみられた珓筋部巽和感は消失し，機能的にも何ら跻 害はなかった。

\section{考察}

咬筋肥大症の成因は明らかでないが，chewing や目 部の griding $に よ る$ work hypertrophy theory ${ }^{2,12 \sim 15)}$ 中

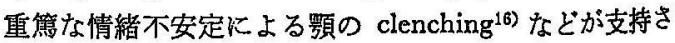




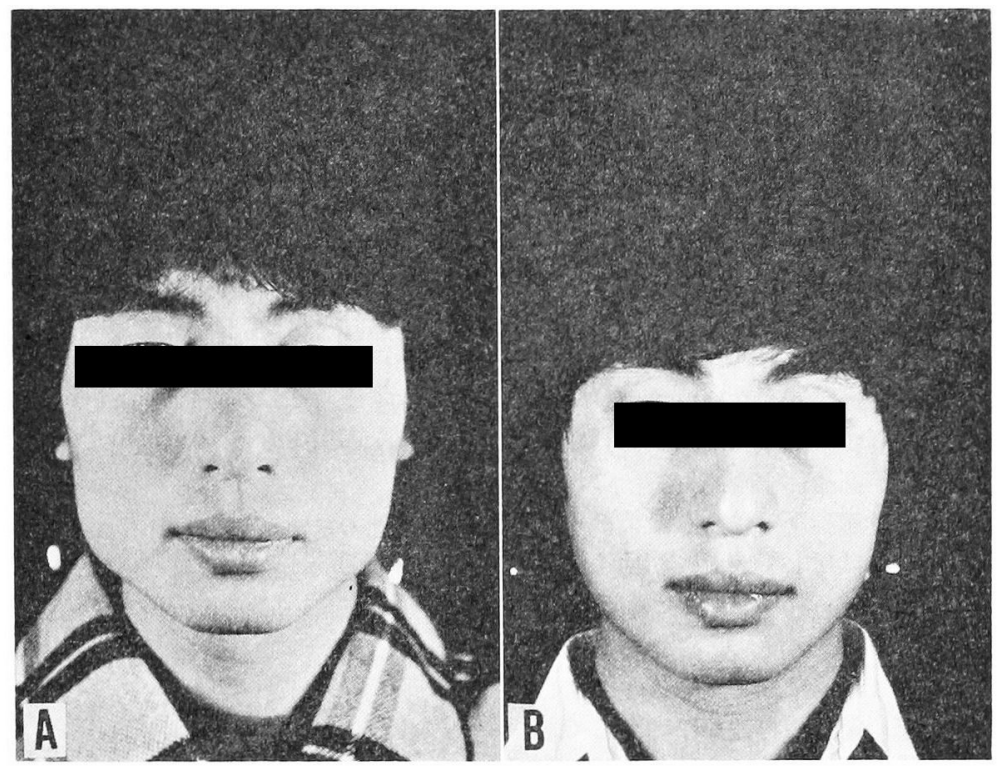

写真 7 症例 2 の颜貌所見

A：政前正貌所見，B：徏後正貌所見

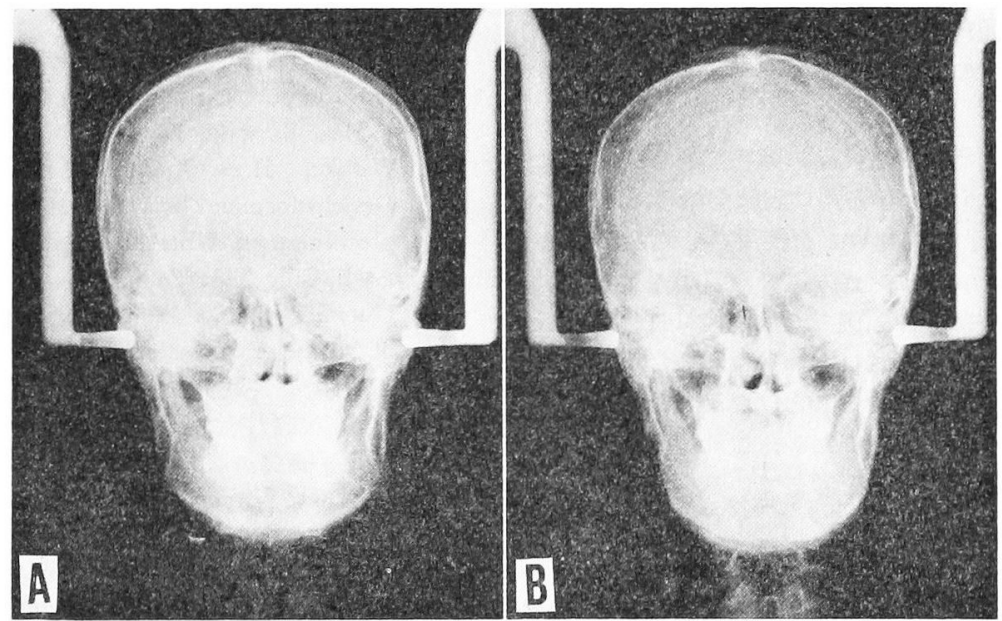

写真 8 症例 2 の頭部X線規格写真

A : 術 前, B : 得 後

れている，Beckers ${ }^{1)}$ は咬筋肥大症17例中10例は原因不 明であったが，その他の症例では下顎部外傷の既往歴， bruxism の習慣ないし咬合異常がみられたと述べ，本症 は顠口腔系の不正ないし外傷性作用によって発現する素 質由来変形 predisposition-induced deformity であると 考えている。は Barton ${ }^{17)}$ は本症を先天型ないし遺伝 型と後天型に分けている，わたくしたらの症例の発生原 因す明らかでなかったが，症例 Iで軽度の精神不安定と 下顎前突症がみられ，症例 2 でも同様に精神不安定が認
められた。しかし，いずれの䒚例も外傷の既往歴はなか った.

Beckers $^{12}$ は咬筋肥大症を变形の程度によって（I）咬 みしぬ時, 視診および触診によって肥大のわかるもの， （II）視診によって肥大がわかり，さらに側貌によって 下顎角の減少が認められるもの，（III）咬笳付着部の骨 の張開のみられるるのの3 型に分類しているが，わたく

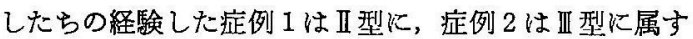
るものと思われた。 
咬筋肥大症の治療法には保存的療法と外科的療法とが あるが，前者は機能障害を主訴とするものに，後者は審 美的障害を主訴とするすのに適応すべきである. 特に審 美的障害の改善は保存的療法では達成されず, 外科的療 法によらざるを得ないり，乙かし外科的療法は決して本 症の原因療法とはならないといわれている。

咬筋肥大症の修正手術法には口外法 ${ }^{2 ~ 6)}$ と口内法 ${ }^{1,7 \sim 10)}$, 外側咬筋切除法 2 , 7) と内側咬筋切除法 ${ }^{1,3,5,6,8,10)}$, また下 䫇角部の骨切除を行ら方法 ${ }^{1,3,6,9)}$ と行わない方法7) とが ある. 口内法は顔面に術後症痕が残らないばかりでな く, 顔面神経下顎縁枝を損傷する危険性が少ない利点が ある。外側咬筋切除法は咬筋膨隆部を確認して, これを 切除するものであるが，全身麻酔下では筋膨隆部を確認 することが困難である．これに対して内側咬筋切除法は 顔面神経頓筇枝および下颚縁枝, 耳下腺管などを損傷す る危険性が少ない利点がある ${ }^{6}$. Beckers ${ }^{1)}$ は内側咬筋は 紡錘状筋線維を多く含むので, 同部筋切除によって遠心 性筇調節機構に変化が生じ, 術後の再発を予防するであ

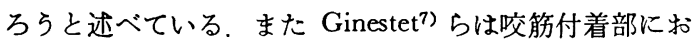
ける筋力低下によって下顎角部の骨性張開は自然に消失 するので，同部の骨切除は必要ないと考兄，下顎角部の 骨切除を行っていないか，術後早期からの審美的改善を 得るためには，下䫓角部の骨切除を推奖するものが多 く，特に Beckers ${ }^{1)}$ のII 型および型でこれが必要であ る.

術後に多くみられる継発症は開口障害である。そのた め Beckers ${ }^{1)}$ は術後 5 日目から開口訓練を始め, さらに 就寝中にも screw 付きの splint を使用させている。

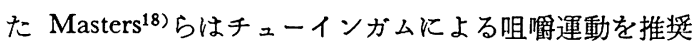
している.わたくしたちは症例 1 では術後21日目から， 症例 2 では術後 5 日目から開口訓練を行わせたが， 2 例 ともに開口障害が長く残遺することはなかった。なお， わたくしたちは持続吸引を用いたが，これがまた開口障 害の予防に有効であったものと考えている。

下頸前突症は正常人に比べて gonial angle 拉よび mandibular plane angle の開大と ramus angle の減少 を示すことが多いが'19)，まれに，これらが逆の傾向を示 し，下靧角の発育がよく，咬筋肥大症を伴うことがあ る.このような症例付して通常の下顎前突症手術のみ を行っても下䫓角部の十分な形態改善は得られない. Eubanks ${ }^{20)}$ は咬筋肥大症を伴う下䫇前突症に対して，口 外法による下䫇前突症手術と咬筋肥大症手術を one stage に行っている。わたくしたちも症例 1 に扣いて雨 側咬管肥大症手術之同時に下顎前方歯槽部骨切り術 ${ }^{21)}$ 行い，良好な結果を得た。 また，わたくしたちは勃起性 咬筋血管腫に 対して Obwegeser-Beckers 法による咬筋 肥大症手術に準じた手術を行い，湍足すべき結果を得て いる22).

\section{む す び}

咬筋肥大症の 2 例に対して Obwegeser-Beckers 法に よる手術を行い，良好な結果を得た。そのらち1例に対 しては本手術と同時に下顎前方歯槽部骨切り術を施し た. Obwegeser-Beckers 法における手術野明視のために fiber optics 付銁が有効である. また 手術部の持続吸引 は術後における開口障害の発生予防に役立つものと思わ れる. 本手術法は咬筋内に発生した腫瘍, その他病变の 摘出にも応用できる。

本詥文の要旨は第 113 回日本口腔外科学会関東地方会 （東京）に打いて発表した。

\section{引用 文 献}

1) Beckers, H.L.: Masseteric muscle hypertrophy and its intraoral surgical correction. $\mathbf{J}$ Maxillofac Surg 5: 281977.

2) Gurney, C.E.: Chronic bilateral benign hypertrophy of the masseter muscles. Amer J Surg 73: 1371947.

3) Adams, W.M.: Bilateral hypertrophy of masseter muscle. An operation for correction. $\mathrm{Br}$ J Plast Surg 2: 781949.

4) Gelbke, H.: Operative Korrektur eckiger Gesichtsformen bei Masseterhyperplasie und prominentem Unterkieferwinkel. Langenbecks Arch Chir 288: 2481958.

5) Ginwalla, M.S.: Bilateral benign hypertrophy of masseter muscle. J Oral Surg 19: 428 1961.

6）高橋庄二郎, 立川 潤, 他: 片側性咬筋肥大症 の 1 手術例。 日外誌 18: 1771972.

7) Ginestet, G., Frezieres, H., et al.: La corection chirurgicale de l'hypertrophie du masseter. Ann Chir Plast 4: 1871959.

8) Perko, M.: Hipertrofijamasetera. Chir Maxillofac Plast 4: Fasc 1 1963. 交献 1 上り引用.

9) Converse, J.M.: Reconstructive plastic surgery vol 3. ed 2, W.B. Saunders Co, Philadelphia, 1977, p 1404.

10) Hankey, G.T.: Surgical reduction of bilateral hypertrophy of the masseter muscles. $\mathrm{Br} \mathrm{J}$ Oral Surg 6: 1231968.

11）高橋庄二郎, 重松知寛, 他: 口腔外科における fiber optics の応用。 口科誌 28: 3061979.

12) Kern, A.B.: Masseter muscle hypertrophy. Arch Dermatol Res 69: 5581954.

13) Caldwell, J.B., Hughes, K.W.: Hypertrophy of the masseter muscles and mandible. $\mathrm{J}$ Oral Surg 15: 3291957. 
14) Oppenheim, H., Wing, M.: Benign hypertrophy of the masseter muscle. Arch Otolaryngol 70: 2071959.

15) Martensson, G.: Hypertrophy of the masster muscle. Acta Otolaryngol 50: 5261959.

16) Hersh, J.H.: Hypertrophy of the masseter muscle. Arch Otolaryngol 43: 5931946.

17) Barton, R.T.: Benign masseteric hypertrophy. JAMA 164: 16461957.

18) Masters, F., Georgiade, N., et al.: Surgical treatment of benign masseteric hypertrophy. Plast Reconstr Surg 15: 2151955.
19）伊藤利明：頭部X線規格写真に上る下顎前突症 患者の䫆面頭蓋に関する形態学的研究, とくに 外科的立場から。桏科学報 77: 4091977.

20) Eubanks, R.J.: Surgical correction of masseter muscle hypertrophy associated with unilateral prognathism. J Oral Surg 15: 661957.

21）高橋庄二郎，重松知宽，他：下䫇前方迷槽部骨 切りに上る䫇発育異常手術。日口外誌 26：378 1980.

22）丸森雅由，木村利男，他：勃起性咬筇血管㓳の 1 例。日口外誌 25: 6641979 . 